Article

\title{
Improvement in Flavonoids and Phenolic Acids Production and Pharmaceutical Quality of Sweet Basil (Ocimum basilicum L.) by Ultraviolet-B Irradiation
}

\author{
Ali Ghasemzadeh ${ }^{1}$, , Sadegh Ashkani ${ }^{2}$, Ali Baghdadi ${ }^{1}$, Alireza Pazoki ${ }^{2}$, Hawa Z. E. Jaafar ${ }^{1}$ \\ and Asmah Rahmat ${ }^{3}$ \\ 1 Department of Crop Science, Faculty of Agriculture, Universiti Putra Malaysia, 43400 Serdang, Selangor, \\ Malaysia; ali_baghdadi@yahoo.com (A.B.); hawazej@upm.edu.my (H.Z.E.J.) \\ 2 Department of Agronomy and Plant Breeding, Yadegar-e-Imam Khomeini (RAH) Shahre Rey Branch, \\ Islamic Azad University, Tehran, Iran; ashkani.sadegh@gmail.com (S.A.); pazoki_agri@yahoo.com (A.P.) \\ 3 Department of Nutrition and Dietetics, Faculty of Medicine and Health Sciences, Universiti Putra Malaysia, \\ 43400 Serdang, Selangor, Malaysia; profasmah@gmail.com \\ * Correspondence: alighasemzadeh@upm.edu.my or upmali@yahoo.com; Tel.: +60-17-291-7679 \\ Academic Editor: Derek J. McPhee \\ Received: 18 July 2016; Accepted: 3 September 2016; Published: 9 September 2016
}

\begin{abstract}
Sweet basil (Ocimum basilicum Linnaeus) is aromatic herb that has been utilized in traditional medicine. To improve the phytochemical constituents and pharmaceutical quality of sweet basil leaves, ultraviolet (UV)-B irradiation at different intensities $\left(2.30,3.60\right.$, and $\left.4.80 \mathrm{~W} / \mathrm{m}^{2}\right)$ and durations $(4,6,8$, and 10-h) was applied at the post-harvest stage. Total flavonoid content (TFC) and total phenolic content (TPC) were measured using spectrophotometric method, and individual flavonoids and phenolic acids were identified using ultra-high performance liquid chromatography. As a key enzyme for the metabolism of flavonoids, chalcone synthase (CHS) activity, was measured using a CHS assay. Antioxidant activity and antiproliferative activity of extracts against a breast cancer cell line (MCF-7) were evaluated using 1,1-diphenyl-2-picrylhydrazyl (DPPH) assays and MTT (3-(4,5-dimethylthiazol-2-yl)-2,5-diphenyltetrazolium bromide) assays, respectively. UV-B irradiation at an intensity of $3.60 \mathrm{~W} / \mathrm{m}^{2}$ increased TFC approximately 0.85 -fold and also increased quercetin (0.41-fold), catechin (0.85-fold), kaempferol (0.65-fold) rutin (0.68-fold) and luteolin (1.00-fold) content. The highest TPC and individual phenolic acid (gallic acid, cinnamic acid and ferulic acid) was observed in the $3.60 \mathrm{~W} / \mathrm{m}^{2}$ of UV-B treatment. Cinnamic acid and luteolin were not detected in the control plants, production being induced by UV-B irradiation. Production of these secondary metabolites was also significantly influenced by the duration of UV-B irradiation. Irradiation for 8-h led to higher TFC, TPC and individual flavonoids and phenolic acids than for the other durations (4, 8, and 10-h) except for cinnamic acid, which was detected at higher concentration when irradiated for 6-h. Irradiation for 10-h significantly decreased the secondary metabolite production in sweet basil leaves. CHS activity was induced by UV-B irradiation and highest activity was observed at $3.60 \mathrm{~W} / \mathrm{m}^{2}$ of UV-B irradiation. UV-B treated leaves presented the highest DPPH activity and antiproliferative activity with a half-maximal inhibitory concentration $\left(\mathrm{IC}_{50}\right)$ value of 56.0 and $40.8 \mu \mathrm{g} / \mathrm{mL}$, respectively, over that of the control plants $(78.0$ and $58.2 \mu \mathrm{g} / \mathrm{mL}$, respectively). These observations suggest that post-harvest irradiation with UV-B can be considered a promising technique to improve the healthy-nutritional and pharmaceutical properties of sweet basil leaves.
\end{abstract}

Keywords: Ocimum basilicum L.; UV-B; TFC; TPC; CHS activity; antioxidant activity; antiproliferative activity 


\section{Introduction}

Flavonoids, which are important secondary metabolites in plants, are involved in resisting environmental stress and regulating the growth of plants [1]. Abundant in leaves, flowers, fruits, and roots, they play important roles in herbal medicines and healthy food products. The biosynthesis of flavonoids in plants begins with the shikimate pathway, and intermediate products, such as chalcone and isoflavonoids, are formed via the phenylpropanoid pathway [2,3]. These flavonoids are then conjugated to other flavonoids and glycose to form final products including anthocyanin and flavonol glycoside. However, the enzymes in these biosynthesis pathways (CHS and phenylalanine ammonia-lyase) are affected by many environmental factors including light, temperature, and concentration of $\mathrm{CO}_{2}$, soil nutrients, and water [4-6]. Nascimento et al. [7] showed that ultraviolet (UV) light greatly influences phytochemical and antioxidant activities in Kalanchoe pinnata. UV-B irradiation has been recommended by several studies as a mean to enhance the nutritional quality of fruits and crops [8-10]. The DNA and tissues of plants can be injured by UV-B irradiation [11]. High levels of UV irradiation, lead to increased concentrations of antioxidants in plants and is considered as a tool for enhancing contents of bioactive compounds in fresh crops, herbs, fruit and vegetables after harvest [12,13]. Therefore, to find an optimized condition that increases flavonoids primarily in the leaves, there have been increased research studies on exposing plants to UV-B irradiation at different temperatures or air components, as well as comparing the effects owing to the age of the leaves. It has been reported that irradiating parsley (Petroselinum hortense) with UV-B over certain durations causes a 4-fold increase in the quantity of flavonoids [14]. Furthermore, Sun et al. [15] showed that for three different ages of Ginkgo biloba leaves, significant differences in the changes of the amount of flavonoids after UV-B irradiation were obtained. Moreover, Harbaum-Piayda et al. [16] indicated that the flavonoid content of pakchoi (Brassica campestris) increased significantly after UV-B irradiation under different temperature conditions. Thus, the optimized condition of UV-B irradiation to increase flavonoids differs between species owing to variations in wax content, tissue thickness, enzyme activity, and photoreceptors in the leaves.

Sweet basil (Ocimum basilicum Linnaeus) is an aromatic herb that grows to $20-80 \mathrm{~cm}$ height. The stem is glabrous and woody at the base and leaves are large, green in colour, broadly epitical, $2.5-5 \mathrm{~cm} \times 1-2.5 \mathrm{~cm}$ in size. Flowers are small $(3 \mathrm{~mm})$, red, pink or white in colour and arranged in terminal spikea [17]. Sweet basil is a highly useful plant because the whole plant has been utilized in traditional medicine from antiquity in the form of household remedies against various human ailments. It is a popular herb, valued for its rich and spicy, mildly peppery flavor with a trace of mint and clove, and has been used widely for flavoring confectionary as well as other food products. Today, healthy food products are prepared from sweet basil leaves and are commonly utilized in traditional medicine to relieve stress, prevent gout, and for other health benefits [18]. Recently, many researchers have reported that there are various kinds of flavonoids in sweet basil leaves that have antioxidant [18], anti-inflammatory [19], anticancer [20], antimicrobial [21], and wound-healing [22] activities. Phytochemical constituents of sweet basil has been investigated by several studies and by now more than 200 phytochemical compounds like as monoterpenes, limonene, myrcene, terpinolene, flavonoids (quercetin, kaempferol, rutin), phenolic acids ( $p$-coumaric acid, caffeic acid, caftaric acid), steroids and vitamins (A, C, E, K) have been identified in this herb [23]. Therefore, the possibility of using simple methods to increase flavonoid content in sweet basil leaves, to enhance the bioactivities in the leaf extract simultaneously, is worthy of further investigation. The majority of studies have utilized UV-B irradiation as a pre-harvest treatment while the plants were growing; however, post-harvest treatment might be more efficient (pre-harvest treatment of UV-B decrease photosynthetic rate and plant growth). The aim of the present study is to evaluate the effect of UV-B irradiation on the phytochemical constituents of sweet basil leaves and its antioxidant and antiproliferative activities. In addition, owing to the various sensitivities to UV-B irradiation in different species, the dosage effects of certain factors (irradiation intensity and irradiation duration) for approaching an optimal condition were studied. 


\section{Results and Discussion}

\subsection{Changes in TFC and TPC under Different UV-B Irradiation Intensities}

The changes in total flavonoid content (TFC) and TPC in the leaves are shown in Table 1. Each irradiation intensity $\left(2.30,3.60\right.$, and $\left.4.80 \mathrm{~W} / \mathrm{m}^{2}\right)$ applied for a duration of 6 -h resulted in a significant increase in TFC, especially in the 2.30 and $3.60 \mathrm{~W} / \mathrm{m}^{2}$ treatments. Irradiating at the $3.60 \mathrm{~W} / \mathrm{m}^{2}$ intensity resulted in a 0.76-fold increase in TFC from $22.26 \mathrm{mg} \mathrm{QE} / \mathrm{g} \mathrm{DM}$ to $39.18 \mathrm{mg} \mathrm{QE} / \mathrm{g}$ DM. However, the higher irradiation intensity $\left(4.80 \mathrm{~W} / \mathrm{m}^{2}\right)$ did not demonstrate a higher level of TFC, indicating that when the intensity is too high, the amount of TFC consumed, which captures the reactive oxygen species (ROS) and repairs the oxidative damage caused by the UV-B irradiation, was almost equal to the increase of TFC [8]. Thus, if the irradiation intensity is higher than $4.80 \mathrm{~W} / \mathrm{m}^{2}$, the amount of TFC may actually decrease. The increase of TFC, showed significant difference between the 2.30 and $3.60 \mathrm{~W} / \mathrm{m}^{2}$ intensities, indicating that both these irradiation intensities are in a suitable range to increase the TFC. However, controlling the $2.30 \mathrm{~W} / \mathrm{m}^{2}$ intensity required more distance between the lamps and leaves than for the $3.60 \mathrm{~W} / \mathrm{m}^{2}$ intensity, and the longer distance increased the amount of space needed, which might make the post-treatment more inconvenient. Therefore, $3.60 \mathrm{~W} / \mathrm{m}^{2}$ was the most appropriate intensity to implement to increase the amount of TFC.

On the other hand, after irradiation with different intensities of UV-B, the quantities of TPC in sweet basil leaves increased from $48.22 \mathrm{mg}$ GAE/g DM in the control plants to $50.41 \mathrm{mg} \mathrm{GAE} / \mathrm{g}$ $\mathrm{DM}$ in $2.30 \mathrm{~W} / \mathrm{m}^{2}$ intensity, $56.12 \mathrm{mg} \mathrm{GAE} / \mathrm{g}$ DM $\left(3.60 \mathrm{~W} / \mathrm{m}^{2}\right)$, and decreased to $49.16 \mathrm{mg} \mathrm{GAE} / \mathrm{g}$ DM when exposed to $4.80 \mathrm{~W} / \mathrm{m}^{2}$ of UV-B irradiation (Table 1). Our findings are consistent with Schreiner et al. [10] who discovered that TPC in Tropaeol majus leaves increased after irradiation with UV-B. Moreover, the results in Table 1 show that TPC increased further when irradiation intensities of UV-B shifted from $2.30 \mathrm{~W} / \mathrm{m}^{2}$ to $3.60 \mathrm{~W} / \mathrm{m}^{2}$. Thus, there appears to be a correlation between irradiation intensities of UV-B and TPC. Eichholz et al. [9] indicated that UV-B irradiation could enhance phenylalanine ammonia-lyase and peroxidase activities to promote the derivatization and polymerization of phenolic compounds such as flavonoids. In addition, plants produce higher amounts of ROS as signals after UV-B irradiation, and ROS can be quenched by phenolic compounds [24]. Hence, after irradiation, TPC in sweet basil leaves might be the precursor for flavonoid biosynthesis and be decreased in other pathways, such as the reactions with peroxidase and ROS when the intensity of UV-B irradiation was too high.

Several identification and separation techniques have previously been reported in order to identify secondary metabolites from plant materials [25-27]. In the present study, three phenolic acids (gallic acid, cinnamic acid, and ferulic acid) and five flavonoids (quercetin, catechin, kaempferol, rutin and luteolin) were identified in the sweet basil leaf extracts using ultra-high performance liquid chromatography (Table 1). With increasing UV-B irradiation from 2.30 to $4.80 \mathrm{~W} / \mathrm{m}^{2}$, the amount of gallic acid and ferulic acid increased significantly in sweet basil leaves compared to control plants. More interestingly, cinnamic acid was not detected in the control plant extracts, but was detected in the leaves of plants exposed to UV-B radiation. Similar to gallic acid and ferulic acid, with increasing UV-B radiation intensity from 2.30 to $4.80 \mathrm{~W} / \mathrm{m}^{2}$ the amount of cinnamic acid increased significantly from $3.24 \mathrm{mg} / \mathrm{g}$ DM to $3.91 \mathrm{mg} / \mathrm{g}$ DM. More interestingly, ferulic acid was not detected at higher UV-B irradiation $\left(4.80 \mathrm{~W} / \mathrm{m}^{2}\right)$. Individual flavonoids showed the same results as the phenolic acids. Increasing UV-B irradiation intensity from 2.30 to $4.80 \mathrm{~W} / \mathrm{m}^{2}$ resulted in an increase in the amount of quercetin, catechin, and kaempferol in the leaf extracts than that in the control plants. The highest content of quercetin $(3.87 \mathrm{mg} / \mathrm{g} \mathrm{DM})$, catechin $(4.0 \mathrm{mg} / \mathrm{g} \mathrm{DM})$, kaempferol $(2.90 \mathrm{mg} / \mathrm{g} \mathrm{DM})$ and rutin $(1.96 \mathrm{mg} / \mathrm{g} \mathrm{DM})$ was obtained from leaf extracts exposed to $3.60 \mathrm{~W} / \mathrm{m}^{2}$ of UV-B irradiation. Luteolin was not detected from control plants and its synthesis was induced by UV-B irradiation. The highest content of luteolin $(0.88 \mathrm{mg} / \mathrm{g} \mathrm{DM})$ was observed at $2.30 \mathrm{~W} / \mathrm{m}^{2}$ of UV-B irradiation but there is no significant differences between 2.30 and $3.60 \mathrm{~W} / \mathrm{m}^{2}$ of UV-B irradiation for luteolin 
content. With increasing UV-B irradiation from 3.60 to $4.80 \mathrm{~W} / \mathrm{m}^{2}$, the amount of flavonoid compounds decreased significantly $(p<0.05)$.

Although the intensity of UV-B irradiation affects flavonoids of sweet basil leaves, the mechanisms of flavonoid biosynthesis differ between species. For example, Olsson et al. [28], who assessed the effects of UV-B irradiation on Brassica napus, reported that quercetin glucoside content increased to a greater extent than did the kaempferol glucoside content, revealing that the quercetin-type flavonoids increased more than the kaempferol-type flavonoids. However, the increased ratio of quercetin in Ginkgo biloba leaves was the same as that of kaempferol in the research of Sun et al. [15]. Overall, these studies showed various patterns in the biosynthesis of diverse kinds of flavonoids between different species. However, the reasons for these different patterns have not been clearly determined, but it is important to understand these patterns for different applications of various species. Hence, the different mechanisms of biosynthesis between species of plants and structure of flavonoids are worthy of continued investigation.

\subsection{Changes of TFC and TPC under Different UV-B Irradiation Durations}

To understand the effects of UV-B irradiation duration on TFC and TPC, sweet basil leaves were irradiated under identical conditions of $25^{\circ} \mathrm{C}$ temperature, $90 \%$ relative humidity, and $3.60 \mathrm{~W} / \mathrm{m}^{2}$ irradiation intensity, with various irradiation durations $(4,6,8$, and 10-h). The results showed that TFC increased significantly $(p<0.05)$ after the $4-8 \mathrm{~h}$ UV-B irradiation durations (Table 2$)$. After the 4-h irradiation, TFC increased from $20.88 \mathrm{mg}$ QE/g DM to $37.76 \mathrm{mg}$ QE/g DM, and following 6-h irradiation, TFC increased to $40.11 \mathrm{mg}$ QE/g DM. After 8-h irradiation, TFC increased to $41.19 \mathrm{mg}$ QE/g DM; however, this increase was not significant compared to 6-h irradiation. In contrast, following 10-h irradiation, TFC decreased significantly to $28.11 \mathrm{mg}$ QE/g DM, which was lower than the value after 4-h irradiation. Sun et al. [15] reported TFC of approximately a 1.56-fold increase in mature leaves of G. biloba after 2-h irradiation and a 1.57-fold increase after 4-h irradiation. These results indicate that irradiation for specific durations might lead to the maximum increase in the ratio of TFC. Because leaf tissues might be damaged by an overdose of UV-B irradiation, the TFC would be rapidly consumed to protect the leaves $[29,30]$. In addition, there was the highest threshold for UV-B irradiation to increase TFC, with the increasing ratio of TFC decreased after longer irradiation durations. Therefore, applying moderate irradiation durations is the most efficient method to increase TFC. According to these results, both 6 -h and 8-h irradiation durations were ideal for increasing the TFC of sweet basil leaves. However, when considering the cost of longer irradiation duration, the 6-h irradiation duration was more efficient, and so it was chosen for subsequent experiments. As can be seen in Table 2, individual flavonoid content increased with the increase in irradiation time from 4 to 8-h; however, after 8 to 10-h irradiation, this decreased significantly. The highest content of quercetin (3.85 mg/g DM), catechin (4.67 mg/g DM), kaempferol (3.80 mg/g DM), rutin (2.12 mg/g DM) and luteolin $(0.96 \mathrm{mg} / \mathrm{g} \mathrm{DM})$ were observed at $8 \mathrm{~h}$ of UV-B irradiation. For luteolin synthesis no significant differences was observed between 6 and 8-h. UV-B radiation induces the synthesis of key enzymes of the phenylpropanoid pathway; thus, under enhanced UV-B radiation, plants usually increase de novo synthesis of flavonoids [31,32]. 
Table 1. Effect of UV-B irradiation on TFC, TPC and individual flavonoid and phenolic acids content from sweet basil leaf extracts.

\begin{tabular}{|c|c|c|c|c|c|c|c|c|c|c|}
\hline $\begin{array}{l}\text { UV-B } \\
\left(\mathrm{W} / \mathrm{m}^{2}\right)\end{array}$ & $\begin{array}{c}\text { TFC } \\
\text { (mg QE/g DM) }\end{array}$ & $\begin{array}{c}\text { TPC } \\
\text { (mg GAE/g DM) }\end{array}$ & $\begin{array}{l}\text { Gallic Acid } \\
\text { (mg/g DM) }\end{array}$ & $\begin{array}{c}\text { Cinnamic Acid } \\
\text { (mg/g DM) }\end{array}$ & $\begin{array}{c}\text { Ferulic Acid } \\
\text { (mg/g DM) }\end{array}$ & $\begin{array}{l}\text { Quercetin } \\
\text { (mg/g DM) }\end{array}$ & $\begin{array}{l}\text { Catechin } \\
\text { (mg/g DM) }\end{array}$ & $\begin{array}{l}\text { Kaempferol } \\
\text { (mg/g DM) }\end{array}$ & $\begin{array}{c}\text { Rutin } \\
\text { (mg/g DM) }\end{array}$ & $\begin{array}{l}\text { Luteolin } \\
\text { (mg/g DM) }\end{array}$ \\
\hline Control & $22.26 \pm 1.57^{d}$ & $48.22 \pm 2.12^{b}$ & $4.76 \pm 0.344^{c}$ & ND & $3.29 \pm 0.209^{c}$ & $2.73 \pm 0.183^{c}$ & $2.16 \pm 0.156^{d}$ & $1.75 \pm 0.155^{\mathrm{d}}$ & $1.16 \pm 0.112^{c}$ & ND \\
\hline 2.30 & $37.18 \pm 1.19^{b}$ & $50.41 \pm 3.21^{b}$ & $5.22 \pm 0.275^{b}$ & $3.24 \pm 0.215^{b}$ & $4.10 \pm 0.224^{b}$ & $3.48 \pm 0.325^{b}$ & $3.50 \pm 0.176^{b}$ & $2.44 \pm 0.162^{b}$ & $1.52 \pm 0.106^{b}$ & $0.88 \pm 0.053^{\mathrm{a}}$ \\
\hline 3.60 & $41.25 \pm 1.88^{a}$ & $56.12 \pm 3.45^{\mathrm{a}}$ & $6.46 \pm 0.311^{a}$ & $3.91 \pm 0.264^{\mathrm{a}}$ & $4.88 \pm 0.218^{a}$ & $3.87 \pm 0.266^{a}$ & $4.00 \pm 0.325^{\mathrm{a}}$ & $2.90 \pm 0.255^{\mathrm{a}}$ & $1.96 \pm 0.124^{a}$ & $0.86 \pm 0.070^{\mathrm{a}}$ \\
\hline 4.80 & $27.62 \pm 1.27^{\mathrm{c}}$ & $49.16 \pm 2.16^{b}$ & $4.11 \pm 0.282^{\mathrm{d}}$ & $3.08 \pm 0.372^{b}$ & ND & $3.10 \pm 0.304^{b}$ & $3.10 \pm 0.224^{c}$ & $2.12 \pm 0.183^{c}$ & $0.93 \pm 0.067^{\mathrm{d}}$ & $0.64 \pm 0.046^{b}$ \\
\hline
\end{tabular}

Data are means of triplicate measurements \pm standard deviation. Means not sharing a common single letter in each column for each measurement were significantly different at $p<0.05$. ND: not detected.

Table 2. Effect of UV-B irradiation time on TFC, TPC and individual flavonoid and phenolic acids content from sweet basil leaf extracts (UV-B: $\left.3.60 \mathrm{~W} / \mathrm{m}^{2}\right)$.

\begin{tabular}{|c|c|c|c|c|c|c|c|c|c|c|}
\hline Time (h) & $\begin{array}{c}\text { TFC } \\
\text { (mg QE/g DM) }\end{array}$ & $\begin{array}{c}\text { TPC } \\
\text { (mg GAE/g DM) }\end{array}$ & $\begin{array}{l}\text { Gallic Acid } \\
\text { (mg/g DM) }\end{array}$ & $\begin{array}{c}\text { Cinnamic Acid } \\
\text { (mg/g DM) }\end{array}$ & $\begin{array}{l}\text { Ferulic Acid } \\
\text { (mg/g DM) }\end{array}$ & $\begin{array}{l}\text { Quercetin } \\
\text { (mg/g DM) }\end{array}$ & $\begin{array}{l}\text { Catechin } \\
\text { (mg/g DM) }\end{array}$ & $\begin{array}{l}\text { Kaempferol } \\
\text { (mg/g DM) }\end{array}$ & $\begin{array}{c}\text { Rutin } \\
\text { (mg/g DM) }\end{array}$ & $\begin{array}{l}\text { Luteolin } \\
\text { (mg/g DM) }\end{array}$ \\
\hline Control & $20.88 \pm 1.40^{\mathrm{d}}$ & $44.52 \pm 2.29^{\mathrm{d}}$ & $4.32 \pm 0.324^{c}$ & ND & $2.43 \pm 0.144^{d}$ & $2.82 \pm 0.142^{c}$ & $2.44 \pm 0.165^{\mathrm{e}}$ & $1.59 \pm 0.140^{\mathrm{e}}$ & $1.27 \pm 0.138^{b}$ & ND \\
\hline 4 & $37.76 \pm 1.52^{b}$ & $47.53 \pm 2.57^{c}$ & $4.59 \pm 0.208^{c}$ & $3.41 \pm 0.146^{b}$ & $3.16 \pm 0.173^{c}$ & $3.24 \pm 0.226^{b}$ & $3.86 \pm 0.328^{c}$ & $2.74 \pm 0.216^{c}$ & $1.50 \pm 0.109^{b}$ & $0.70 \pm 0.081^{b}$ \\
\hline 6 & $40.11 \pm 1.29^{a}$ & $51.12 \pm 2.73^{b}$ & $5.12 \pm 0.264^{b}$ & $3.96 \pm 0.188^{a}$ & $4.55 \pm 0.269^{b}$ & $3.45 \pm 0.247^{b}$ & $4.24 \pm 0.237^{b}$ & $3.18 \pm 0.227^{b}$ & $1.53 \pm 0.122^{b}$ & $0.93 \pm 0.056^{\mathrm{a}}$ \\
\hline 8 & $41.19 \pm 1.46^{\mathrm{a}}$ & $55.79 \pm 2.31^{a}$ & $6.07 \pm 0.416^{a}$ & $3.24 \pm 0.247^{b}$ & $5.10 \pm 0.320^{a}$ & $3.85 \pm 0.166^{a}$ & $4.67 \pm 0.216^{a}$ & $3.80 \pm 0.148^{a}$ & $2.12 \pm 0.144^{\mathrm{a}}$ & $0.96 \pm 0.072^{\mathrm{a}}$ \\
\hline 10 & $28.11 \pm 1.75^{c}$ & $43.20 \pm 2.70^{\mathrm{d}}$ & $3.72 \pm 0.244^{d}$ & $3.11 \pm 0.263^{b}$ & $2.10 \pm 0.108^{\mathrm{e}}$ & $2.43 \pm 0.204^{\mathrm{d}}$ & $2.80 \pm 0.155^{d}$ & $2.26 \pm 0.117^{d}$ & $1.00 \pm 0.172^{c}$ & $0.65 \pm 0.059^{b}$ \\
\hline
\end{tabular}

Data are means of triplicate measurements \pm standard deviation. Means not sharing a common single letter in each column for each measurement were significantly different at $p<0.05$. ND: not detected. 
The results from the present study reveal that TPC increased significantly with increasing irradiation time up to 8-h (Table 2). The lowest TPC was observed in the non-treated plants, with TPC increasing from $44.52 \mathrm{mg}$ GAE/g DM in the control plants to $47.53 \mathrm{mg}$ GAE/g DM (4-h), $51.12 \mathrm{mg}$ GAE/g DM (6-h) and 55.79 mg GAE/g DM (8-h). Continuation of irradiation to 10-h decreased TPC significantly to $43.20 \mathrm{mg}$ GAE/g DM, which was lower than control plants. The content of gallic acid, cinnamic acid and ferulic acid in the sweet basil leaves increased significantly with increasing irradiation time. The content of cinnamic acid in sweet basil leaves increased until the 6-h irradiation point and then decreased until the $10-\mathrm{h}$ irradiation time. The highest content of gallic acid $(6.07 \mathrm{mg} / \mathrm{g}$ $\mathrm{DM})$ and ferulic acid (5.10 mg/g DM) was observed at 8-h irradiation, while the highest content of cinnamic acid (3.96 mg/g DM) was observed under the 6-h irradiation duration. After UV-B irradiation, studies have shown that there is an increase in RNA transcription level for enzymes participating in the flavonoid biosynthesis of plants, such as phenylalanine ammonia-lyase, cinnamic acid 4-hydroxylase $(\mathrm{C} 4 \mathrm{H})$, 4-coumarate-CoA ligase (4CL), chalcone synthase (CHS), and flavone synthase (FNS), and their increasing ratios and stimulation durations are not the same $[33,34]$. In RNA transcription of CHS, which is more directly related to flavonoid biosynthesis, this can be sustained at high levels for a long duration [15]. According to these previous studies, it could be hypothesized that during the long irradiation duration and reaction time, the induced flavonoid biosynthesis lasted longer than that of upstream phenol biosynthesis. Therefore, phenolic compounds, which are precursors of flavonoid biosynthesis, were consumed quickly to form flavonoids. In general, irradiation up to 8-h resulted in improving and enhancing of secondary metabolites in sweet basil, but, continuing of irradiation to $10-\mathrm{h}$ resulted in decreasing of secondary metabolites. The results of our study was consistent with Scattino et al. [35] who reported that 12-h irradiation with UV-B resulted in increasing of flavonoids in peach skin, while when irradiation time increased to 24-h flavonoids content decreased significantly. Based on obtained results from phytochemical analysis, $3.60 \mathrm{~W} / \mathrm{m}^{2} \mathrm{UV}-\mathrm{B}$ irradiation for duration of 8-h (with highest flavonoid and phenolic acid contents) and non-treated leaves (as a control) were chosen for evaluation of antioxidant and antiproliferative activities.

\subsection{Chalcone Synthase (CHS, EC 2.3.1.74) Activity}

Enzyme chalcone synthase (CHS, EC 2.3.1.74) has been discovered and reported as a key enzyme for the metabolism of flavonoid in plant cells [36]. In this study, CHS activity in sweet basil leaves was influenced significantly by UV-B irradiation. As can be seen from Figure 1, highest CHS activity was observed at $3.60 \mathrm{~W} / \mathrm{m}^{2}$ followed by 2.30 and $4.80 \mathrm{~W} / \mathrm{m}^{2}$. Control plants represent lowest CHS activity. Induction of CHS enzyme activity by UV-B irradiation was reported by previous studies [37-39]. Flavonoids are derived from 4-coumaroyl-CoA and malonyl-CoA in the presence of CHS. This indicates that CHS is an important enzyme in flavonoid synthesis. According to the current results, it is hypothesized that the increment of polyphenolic compounds in the sweet basil leaves at $3.60 \mathrm{~W} / \mathrm{m}^{2}$ could be attributed to an increase in CHS activity.

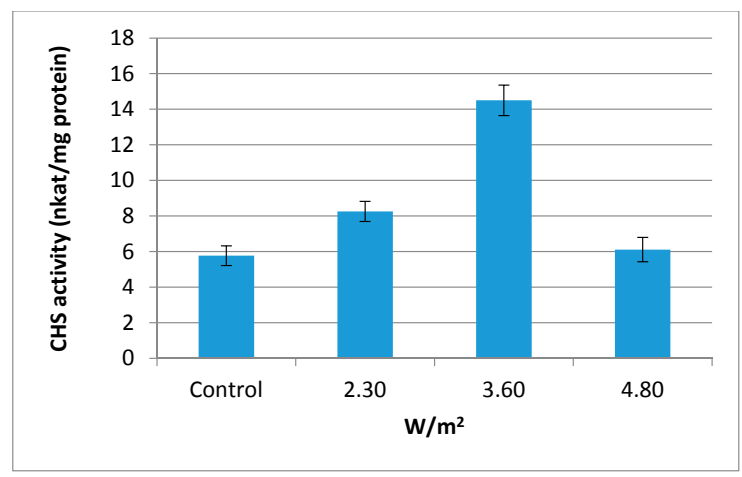

Figure 1. Effect of UV-B irradiation $\left(3.60 \mathrm{~W} / \mathrm{m}^{2}, 8-\mathrm{h}\right)$ on CHS enzyme activity in sweet basil leaves. 


\subsection{Antioxidant Activity}

The results of the assessment of antioxidant activity using the DPPH assay are shown in Figure 2. According to these results, the antioxidant activity of sweet basil leaf extracts was significantly enhanced after using UV-B irradiation treatment $\left(3.60 \mathrm{~W} / \mathrm{m}^{2}, 8-\mathrm{h}\right)$ over that of the extracts from the control plants. The DPPH radical scavenging activity of sweet basil was significantly increased $(p<0.05)$ as sample concentration increased. The half-maximal inhibitory concentration $\left(\mathrm{IC}_{50}\right)$ value of UV-B treated plants was $56 \mu \mathrm{g} / \mathrm{mL}$ while the $\mathrm{IC}_{50}$ of the control plants was $78 \mu \mathrm{g} / \mathrm{mL}$ and ascorbic acid has an $\mathrm{IC}_{50}$ of $41 \mu \mathrm{g} / \mathrm{mL}$. Lower $\mathrm{IC}_{50}$ values represent stronger free radical inhibition and strong free-radical inhibitors are active at low concentrations. From the results of the present study, after the application of UV-B irradiation, the antioxidant activity of the sweet basil leaves significantly increased. This increase could be related to an increase in secondary metabolites such as flavonoids and phenolic acids in UV-B treated plants. Positive correlation between secondary metabolites content and antioxidant activity of herbs has been recorded in previous studies [40-43]. In a more recent study, it was reported that the antioxidant activity of tomato fruit was significantly increased following the increase in secondary metabolites when treated with UV-B irradiation [44]. The results obtained from the present study are consistent with those obtained by Rybarczyk-Plonska et al. [45] and Harbaum-Piayda et al. [46], who reported the induction of secondary metabolites production and enhancement of antioxidant activity in broccoli flower and cabbage leaves, respectively, after UV-B irradiation. Antioxidant activities of 23 varieties of Iranian basil have also been investigated and the results showed that there is positive linear relationship between the total phenolic content and antioxidant activity in all varieties [47].

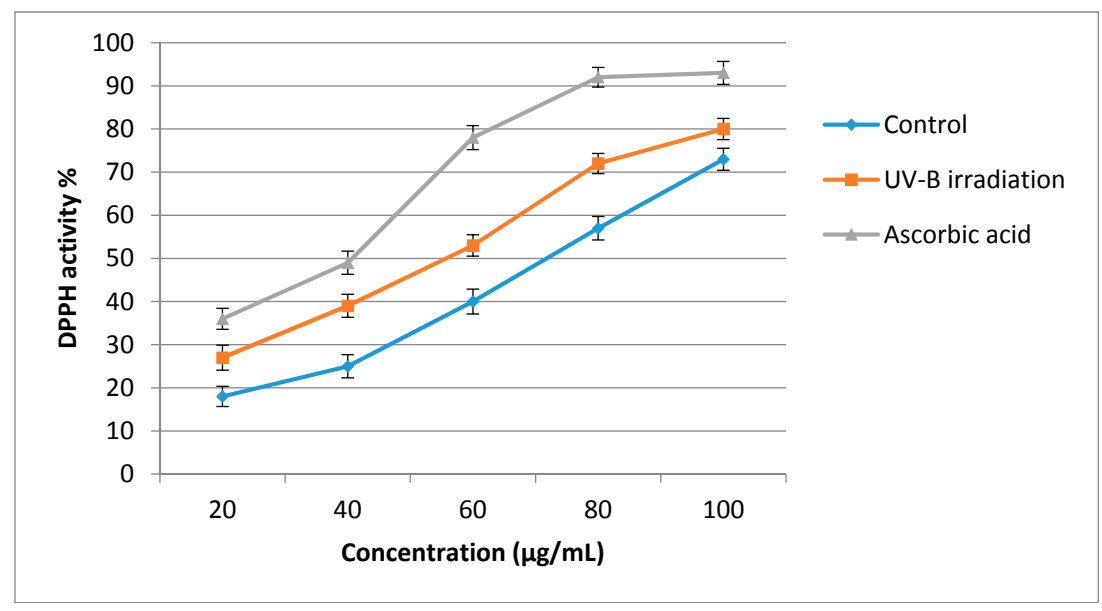

Figure 2. Antioxidant activity of sweet basil non-treated leaves and UV-B treated $\left(3.60 \mathrm{~W} / \mathrm{m}^{2}, 8-\mathrm{h}\right)$ leaves using DPPH assay. Bars represent standard errors of the means.

\subsection{Antiproliferative Activity}

The antiproliferative activities of the sweet basil leaf extracts against the MCF-7 cell line were significantly influenced by UV-B treatment (Figure 3). In the control plants, when plant extract concentration was increased from 10 to $160 \mu \mathrm{g} / \mathrm{mL}$, the cancer cell viability decreased from $87.24 \%$ to $22.6 \%$, while in UV-B treated plants the cancer cell viability decreased from $80.20 \%$ to $12.40 \%$. The antiproliferative activity of sweet basil leaf extracts in the control and UV-B treated plants was lower than that of Tamoxifen, which was used as a positive control. The $\mathrm{IC}_{50}$ value of UV-B treated plants against the MCF-7 cell line was $40.8 \mu \mathrm{g} / \mathrm{mL}$, while that of control plants was $58.2 \mu \mathrm{g} / \mathrm{mL}$, and the sweet basil leaves also had higher $\mathrm{IC}_{50}$ value than did tamoxifen $\left(\mathrm{IC}_{50}=17.9 \mu \mathrm{g} / \mathrm{mL}\right.$ ). When the leaf extract concentration was increased from 10 to $160 \mu \mathrm{g} / \mathrm{mL}$, normal cell viability decreased from $88.93 \%$ to $56.83 \%$ in the control plants and from $86.80 \%$ to $54.40 \%$ in the UV-B treated plants. 
At concentration of $40.8 \mu \mathrm{g} / \mathrm{mL}\left(\mathrm{IC}_{50}\right.$ of UV-B treated plants) $78.9 \%$ normal cell viability was observed while, at a concentration of $58.2 \mu \mathrm{g} / \mathrm{mL}\left(\mathrm{IC}_{50}\right.$ of non-treated plants) $76.2 \%$ normal cell viability was recorded (Figure 4). Previous studies have reported that the antiproliferative activity of herbs is associated with their phytochemical content $[40,41,48]$. Antiproliferative activity of sweet basil leaves against the human cervical cancer cell line (HeLa) with $\mathrm{IC}_{50}$ value of $164.6 \mu \mathrm{g} / \mathrm{mL}$ has been reported previously [49]. In a recent study, the cytotoxicity effect of sweet basil leaves were evaluated against HeLa and the human laryngeal epithelial carcinoma cell line, with the results showing that sweet basil represent a potent cytotoxicity effect with $\mathrm{IC}_{50}$ values of 90.5 and $96.3 \mu \mathrm{g} / \mathrm{mL}$, respectively [20]. Arshad et al. [50] reported antiproliferative activity of sweet basil extract against MCF-7 cells with $\mathrm{IC}_{50}$ values of $71 \mu \mathrm{g} / \mathrm{mL}$. These studies all tested the antiproliferative activities of normal sweet basil leaves and, to the best of our knowledge, there is no information regarding the antiproliferative activity of sweet basil leaves treated with UV-B irradiation. Therefore, the results of the present study are useful for future studies.

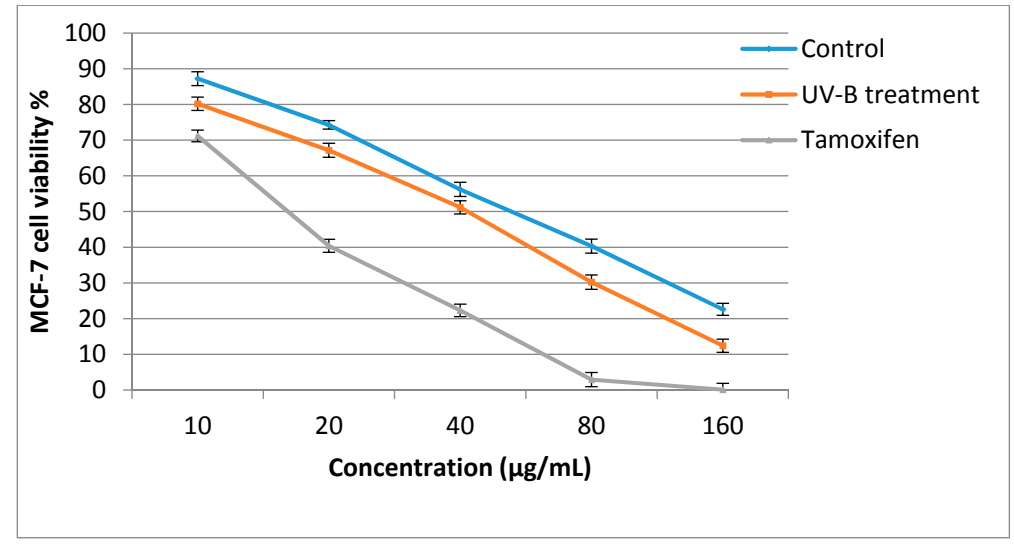

Figure 3. Effect of sweet basil non-treated leaves and UV-B treated $\left(3.60 \mathrm{~W} / \mathrm{m}^{2}, 8-\mathrm{h}\right)$ leaves against breast cancer cell line (MCF-7) viability. Bars represent standard errors of the means.

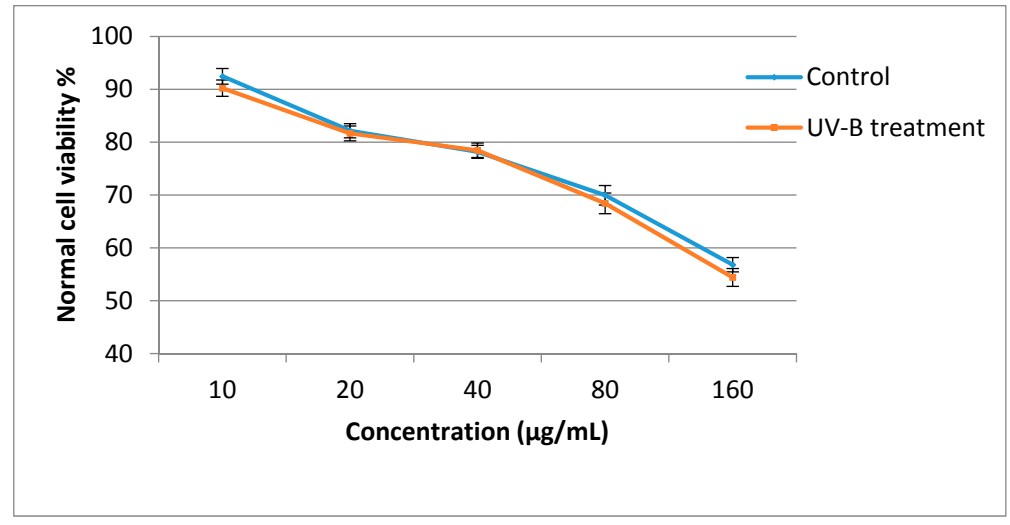

Figure 4. Effect of sweet basil non-treated leaves and UV-B treated $\left(3.60 \mathrm{~W} / \mathrm{m}^{2}, 8-\mathrm{h}\right)$ leaves against normal cell (MCF-10A) viability. Bars represent standard errors of the means.

\subsection{Correlation Analysis}

It is important to evaluate the correlation between biological activity of herbs and secondary metabolites content in order to introduce corresponding compounds for biological activity. Knowing of this could help researchers establish suitable conditions or to use suitable techniques in order to enhance these highlighted compounds. In the current study, correlation analysis between phytochemicals and biological activities of sweet basil extracts was done for optimized UV-B irradiation condition 
(3.60 W/ $\mathrm{m}^{2}$ and 8-h irradiation). Correlation coefficient analyses showed a significant relationship between phytochemical content and breast cancer proliferation. Antiproliferative and antioxidant activity of sweet basil mostly correlated with flavonoids followed by phenolic acids. A negative and significant correlation coefficient was also found between breast cancer proliferation and phytochemicals ranging from $\mathrm{R}^{2}=-0.7433$ to -0.9327 (Table 3). Between identified phytochemicals, quercetin and kaempferol showed a strong negative correlation with MCF-7 $\left(\mathrm{R}^{2} \mathrm{Q}=-0.9327\right.$; $\left.R^{2} K=-0.9240\right)$ cancer proliferation. In current study, positive and significant correlation was observed between phytochemicals and antioxidant activity ranging from $R^{2}=0.8039$ to 0.9315 . Between identified phytochemicals, quercetin $\left(R^{2}=0.9168\right)$ and kaempferol $\left(R^{2}=0.9315\right)$ more correlated with antioxidant activity. Several studies reported a significant correlation between the pharmaceutical activity of herbs and the phytochemical content [41,51]. Based on obtained results it seems that quercetin and kaempferol are responsible phytochemicals for antiproliferative and antioxidant activity of sweet basil.

Table 3. Correlations $\left(\mathrm{R}^{2}\right)$ among human breast cancer cell proliferation, antioxidant activity and identified phytochemicals from sweet basil extracts.

\begin{tabular}{ccc}
\hline Phytochemicals & Antiproliferative Activity & Antioxidant Activity \\
\hline TFC & $-0.9031^{* *}$ & $0.9100^{* *}$ \\
TPC & $-0.8940^{* *}$ & $0.8862^{* *}$ \\
Gallic acid & $-0.8225^{*}$ & $0.8325^{* *}$ \\
Cinnamic acid & $-0.7433^{*}$ & $0.8039^{*}$ \\
Ferulic acid & $-0.8661^{* *}$ & $0.8590^{* *}$ \\
Quercetin & $-0.9327^{* *}$ & $0.9168^{* *}$ \\
Catechin & $-0.8266^{*}$ & $0.8892^{* *}$ \\
Kaempferol & $-0.9240^{* *}$ & $0.9315^{* *}$ \\
Rutin & $-0.8590^{* *}$ & $0.8872^{* *}$ \\
Luteolin & $-0.8229^{*}$ & $0.8126^{*}$ \\
\hline \multicolumn{2}{c}{${ }^{*}$ and ${ }^{* *}$ are significant at $p<0.05$ and 0.01 respectively. }
\end{tabular}

\section{Materials and Methods}

\subsection{Plant Samples}

Sweet basil seeds (genotype: EC778531, Research Institute of Forest and Rangeland, Tehran, Iran) were sterilized with 1\% hypochlorite solution for 2-3 min then washed thoroughly with tap water. All seeds were sown into 77-cell trays containing a soil-sand-peat mixture (1:1:1 ratio, $v / v)$. The seedlings at four weeks of age with three to four leaves were transplanted into $3 \mathrm{~L}$ plastic pots containing a coco peat-burnt rice husk mixture (1:1 ratio, $v / v)$. A medium fertilizer dose of 40:40:40 kg/ha of $\mathrm{N}, \mathrm{P}_{2} \mathrm{O}_{5}$, and $\mathrm{K}_{2} \mathrm{O}$ was added, as this is the recommended dose for economic yield. For irrigation, a super drip irrigation system was utilized. The mean daily temperature $30 \pm 2{ }^{\circ} \mathrm{C}$, mean relative humidity $75 \%-80 \%$ and highest irradiance level at $1480 \mu \mathrm{mol} / \mathrm{m}^{2} / \mathrm{s}$ and whilst minimum at $52 \mu \mathrm{mol} / \mathrm{m}^{2} / \mathrm{s}$. Plants were harvested at four months, with leaves separated after harvesting and washed with tap water.

\subsection{UV-B Radiation}

The UV-B irradiation conditions followed the method reported by Sun et al. [15] with minor modifications. All leaves, placed side by side without overlap, were irradiated under UV-B in a plant growth chamber (GC-101H, Firstek, New Taipei, Taiwan) under fixed humidity (90\%). After UV-B irradiation, the treated samples were stored for $24 \mathrm{~h}$ in darkness to complete the adaptation reaction. Compounds from these treated samples were then extracted using $95 \%$ ethanol for further analysis. To determine the optimal irradiation of UV-B necessary to increase flavonoid levels, groups of samples were irradiated separately using UV-B lamps (TL 40 W/12 RS, 280-320 nm, Philips, Philips, Amsterdam, 
Netherlands) with different irradiation intensities at approximately $2.30,3.60$, and $4.80 \mathrm{~W} / \mathrm{m}^{2}$ at $25{ }^{\circ} \mathrm{C}$ based on preliminary experiments. In addition, samples were irradiated to the optimal irradiation intensity of UV-B for different irradiation durations $(4,6,8$, and 10-h).

\subsection{Preparation of Plant Extracts}

Fresh leaves were dried using a freeze dryer. Dried samples (5 g) were ground into powder followed by extraction with distilled water $(100 \mathrm{~mL})$. Solutions were refluxed for $2-\mathrm{h}$ at $65{ }^{\circ} \mathrm{C}$, then cooled and filtered through filter paper (No. 1, Whatman, Singapore) in a filter funnel, followed by evaporation under reduced pressure in an Eyela rotary evaporator (Miyagi, Japan) to remove excess solvent. Residue was freeze dried and dried extracts were kept at $-20^{\circ} \mathrm{C}$ for future analysis.

\subsection{Estimation of Total Phenolic Content (TPC)}

Total phenolic content was determined using the spectrophotometric method according to the Folin-Ciocalteu assay. Crude extracts $(0.25 \mathrm{mg})$ were dissolved in methanol $(10 \mathrm{~mL})$ and $200 \mu \mathrm{L}$ of the solution was diluted in distilled water $(20 \mathrm{~mL})$. Folin-Ciocalteu reagent (diluted 10-fold; $1 \mathrm{~mL}) \mathrm{was}$ added and the mixture was incubated in total darkness for $10 \mathrm{~min}$ at room temperature. After this time, sodium carbonate $7.5 \%(1 \mathrm{~mL})$ was added and the mixture incubated for $30 \mathrm{~min}$, then the absorbance of the solution was read at $765 \mathrm{~nm}$ using a spectrophotometer (UV2550, Shimadzu, Kyoto, Japan). Different concentrations of gallic acid $(0.062,0.125,0.250,0.500$, and $1 \mathrm{mg} / \mathrm{mL}$ ) were used to prepare the calibration curve. Results were expressed as milligrams of gallic acid equivalents (GAE)/g DM.

\subsection{Estimation of Total Flavonoid Contents (TFC)}

Total flavonoid content of the crude extracts was determined by using the aluminium chloride spectrophotometric method. Crude extract $(0.25 \mathrm{mg})$ was dissolved in methanol $(10 \mathrm{~mL})$. Extracts $(1 \mathrm{~mL})$ were mixed with $\mathrm{NaNO}_{2}$ solution $(4 \mathrm{~mL}, 1: 5, w / v)$ and incubated at room temperature for $6 \mathrm{~min}$. After this time, $\mathrm{AlCl}_{3}$ solution $(0.3 \mathrm{~mL}, 1: 10, w / v)$ was added, the reagents were mixed well, and the reaction was allowed to stand for another $6 \mathrm{~min}$. immediately after that, $1 \mathrm{M} \mathrm{NaOH}$ solution $(2.0 \mathrm{~mL})$ was added to each extract and incubated for $10 \mathrm{~min}$ at room temperature. The absorbance of the solutions was read at $510 \mathrm{~nm}$ using a spectrophotometer (UV2550, Shimadzu). Different concentrations $(0.031,0.062,0.125,0.250,0.500 \mathrm{mg} / \mathrm{mL})$ of quercetin standard were used to prepare a calibration curve. Results were expressed as milligram quercetin equivalents (QE)/g DM. Measurements were performed in triplicate and values are the average of three replicates.

\subsection{Identification of Flavonoids and Phenolic Acids}

Ultra-high performance liquid chromatography (UHPLC, 1290 Infinity Quaternary LC System, Agilent, Santa Clara, CA, USA) was used to separate and identify the phenolic acids. The chromatographic system conditions were set as follows: mobile phase, $0.03 \mathrm{M}$ orthophosphoric acid (A) and methanol HPLC grade (B); detector, UV 280-360 nm; column, C18 column (5.0 $\mu \mathrm{m}, 4.6 \mathrm{~mm}$ inner diameter [ID] $\times 250 \mathrm{~mm}$ ); column oven temperature, $35^{\circ} \mathrm{C}$; and flow rate, $1.0 \mathrm{~mL} / \mathrm{min}$. Gradient elution was performed as follows: 0-10 min, 10\% B; 10-15 min, 50\% B; 15-20 min, 100\% B; and finally 5 min for washing. All standards (gallic acid, cinnamic acid, ferulic acid, quercetin, catechin, kaempferol, rutin and luteolin) were purchased from Sigma-Aldrich (M) Sdn Bhd, Selangor, Malaysia. Linear regression equations were calculated using $Y=a X \pm b$, where $X$ is the concentration of the related compound and $Y$ the peak area of the compound obtained from UHPLC. The linearity was established by the coefficient of determination $\left(\mathrm{R}^{2}\right)$. UHPLC analysis was performed in triplicate and values are the average of three replicates. 


\subsection{Chalcone Synthase (CHS) Assay}

The CHS was extracted from $0.4 \mathrm{~g}$ of leaves with a solution of $1 \mathrm{mM}$ 2-mercaptoethanol dissolved in $0.1 \mathrm{M}$ borate buffer $(1 \mathrm{~mL}, \mathrm{pH} 8.8)$ at $4{ }^{\circ} \mathrm{C}$. Subsequently, Dowex $1 \times 4$ resin $(0.1 \mathrm{~g})$ was added to the solution and the mixture rested for $10 \mathrm{~min}$. The solution was then centrifuged at $15,000 \mathrm{rpm}$ for $10 \mathrm{~min}$ to remove the resin. The supernatant was transferred to a tube, and Dowex resin $(0.2 \mathrm{~g})$ was added and the mixture left standing for $20 \mathrm{~min}$. The resin was removed from solution after centrifugation at $15,000 \mathrm{rpm}$ for $15 \mathrm{~min}$. The supernatant $(100 \mu \mathrm{L})$ was mixed gently with $10 \mathrm{mM}$ potassium cyanide and following that Tris-HCI buffer $(1.89 \mathrm{~mL}, \mathrm{pH} 7.8)$ was added. Subsequently, chalcone $(10 \mathrm{mg})$ was added to ethylene glycol monomethyl ether $(10 \mu \mathrm{L})$, mixed with enzyme extract, and the reaction allowed to proceed for $1 \mathrm{~min}$ at $30^{\circ} \mathrm{C}$. The absorbance was measured at $370 \mathrm{~nm}$.

\subsection{In Vitro Evaluation of Antioxidant Activity}

\section{1,1-Diphenyl-2-picrylhydrazyl (DPPH) Assay}

The DPPH assay was used in order to evaluate the free radical scavenging activity of sweet basil extracts. DPPH was dissolved in methanol at a concentration of $100 \mu \mathrm{M}$. The DPPH solution $(3 \mathrm{~mL})$ was mixed with $3 \mathrm{~mL}$ of various concentrations of plant extracts and incubated in a dark room for $20 \mathrm{~min}$ at $27^{\circ} \mathrm{C}$. After incubation, the absorbance of the samples was read at $517 \mathrm{~nm}$ using a spectrophotometer (UV2550, Shimadzu). Ascorbic acid was used as a positive control. The scavenging activity was calculated using the following formula:

$$
\% \text { inhibition }=[(\text { absorbance control }- \text { absorbance sample }) / \text { absorbance control })] \times 100
$$

\subsection{Determination of AntiProliferative Activity}

\subsubsection{Cell Culture and Treatment}

Estrogen receptor (ER)-positive MCF-7 breast cancer cell and normal cell line (MCF-10A) were procured from the laboratory of Molecular Biomedicine, Institute Bio-science, Universiti Putra Malaysia, Serdang, Selangor, Malaysia. Cells were cultured in RPMI 1640 media containing 10\% fetal bovine serum (FBS). Cell lines were incubated overnight at $37^{\circ} \mathrm{C}$ in $5 \% \mathrm{CO}_{2}$ for cell attachment. The cells were maintained by sub-culturing in $25 \mathrm{~cm}^{2}$ tissue culture flasks. Cells growing in the exponential phase were used for cell viability assay.

\subsubsection{MTT (3-(4,5-Dimethylthiazol-2-yl)-2,5-diphenyltetrazolium bromide) Assay}

The assay was conducted as follows: Cancer cells were seeded in 96-well plates at a density of $1 \times 10^{4}$ cells/well in $100 \mu \mathrm{L}$ of media. After $24 \mathrm{~h}$, the medium was removed and the cells were incubated for 3 days in the presence and absence of various concentrations of sweet basil leaves extract [test extracts were prepared in $0.1 \%$ Dimethyl sulfoxide (DMSO) and serially diluted with media to obtain appropriate concentrations]. The following concentrations of extracts were used: $10-160 \mu \mathrm{g} / \mathrm{mL}$. Cells in the control group received only media containing $0.1 \%$ DMSO. After incubation, the test compound containing media was removed and washed with $200 \mu \mathrm{L}$ of PBS followed by addition of $20 \mu \mathrm{L}$ of MTT reagent $\left(5 \mathrm{mg} / \mathrm{mL}\right.$ MTT in PBS) and incubated for $4 \mathrm{~h}$ at $37^{\circ} \mathrm{C}$. The medium was removed and $100 \mu \mathrm{L}$ DMSO was added and the absorbance measured using a micro plate reader at $540 \mathrm{~nm}$ followed by the calculation of percentage viability. $0.1 \%(v / v)$ DMSO in medium was used as negative control. The cell viability was determined using the formula:

$$
\begin{gathered}
\text { Viability }(\%)=100-(\text { absorbance of cells treated with extract }- \text { absorbance of cells } \\
\text { treated with } 0.1 \% \text { DMSO / absorbance of cells treated with } 0.1 \% \text { DMSO }) \times 100
\end{gathered}
$$

Each point represents the mean of triplicate experiments. 


\subsection{Statistical Analysis}

Statistical analysis was performed using Statistical Analysis System (SAS version 9.2, SAS Institute Inc., Cary, NC, USA). Mean separation test between treatments was performed using Duncan's Multiple Range Test (ANOVA was performed before the Duncan's Multiple Range test) and $p$-value of $<0.05$ was regarded as significant.

\section{Conclusions}

To improve the nutritional quality and health benefits of herbal products, it is necessary both to devise an appropriate method and to identify the most suitable stage for implementation, which should be accomplished not only during the plantation and agronomy periods, but also post-harvest. From the present study, it can be concluded that UV-B irradiation with $3.60 \mathrm{~W} / \mathrm{m}^{2}$ intensity and 8-h duration was the most effective in increasing the quantity of secondary metabolites in sweet basil leaves, leading to improvements in its pharmaceutical quality. UV-B irradiation led to the induction of cinnamic acid synthesis in sweet basil leaves, with this acid not being detected in non-treated plants. Enhancement of flavonoids by UV-B could be attributed to induction of CHS enzyme activity. UV-B treated leaves exhibited more potent antiproliferative activity against a breast cancer cell line (MCF-7) than did the non-treated plants. This demonstrates that the increase of phytochemicals via optimized UV-B irradiation conditions could also enhance bioactivity of the leaf extract, and might improve the potential application of nutraceutical products derived from sweet basil leaves. Antiproliferative and antioxidant activity of sweet basil mostly correlated with flavonoids followed by phenolic acids.

Acknowledgments: The authors would like to thank from all staff of the Laboratory of Nutrition, Department of Nutrition and Dietetics, Faculty of Medicine and Health Sciences, Universiti Putra Malaysia for all their help and guidance in order to accomplish this project.

Author Contributions: Study design and experimental work was by A.G. and S.A. The first draft of the paper was written by A.G. and reviewed by H.Z.E.J., A.B. and A.P. participated antioxidant experiment and data collection and A.R. participated in antiproliferative study and data analysis. All authors reviewed and approved the final version.

Conflicts of Interest: The authors declare no conflict of interest. The founding sponsors had no role in the design of the study; in the collection, analyses, or interpretation of data; in the writing of the manuscript, and in the decision to publish the results.

\section{References}

1. Winkel-Shirley, B. Biosynthesis of flavonoids and effects of stress. Curre. Opin. Plant Biol. 2002, 5, $218-223$. [CrossRef]

2. Koes, R.; Verweij, W.; Quattrocchio, F. Flavonoids: A colorful model for the regulation and evolution of biochemical pathways. Trends Plant Sci. 2005, 10, 236-242. [CrossRef] [PubMed]

3. Dixon, R.A.; Achnine, L.; Kota, P.; Liu, C.J.; Reddy, M.; Wang, L. The phenylpropanoid pathway and plant defence-A genomics perspective. Mol. Plant Pathol. 2002, 3, 371-390. [CrossRef] [PubMed]

4. Ghasemzadeh, A.; Nasiri, A.; Jaafar, H.Z.; Baghdadi, A.; Ahmad, I. Changes in phytochemical synthesis, chalcone synthase activity and pharmaceutical qualities of Sabah snake grass (Clinacanthus nutans L.) in relation to plant age. Molecules 2014, 19, 17632-17648. [CrossRef] [PubMed]

5. Ghasemzadeh, A.; Jaafar, H.Z.; Karimi, E.; Ibrahim, M.H. Combined effect of CO 2 enrichment and foliar application of salicylic acid on the production and antioxidant activities of anthocyanin, flavonoids and isoflavonoids from ginger. BMC Complement. Altern. Med. 2012, 12, 1. [CrossRef] [PubMed]

6. Mori, K.; Sugaya, S.; Gemma, H. Decreased anthocyanin biosynthesis in grape berries grown under elevated night temperature condition. Sci. Hortic. 2005, 105, 319-330. [CrossRef]

7. Dos Santos Nascimento, L.B.; Leal-Costa, M.V.; Menezes, E.A.; Lopes, V.R.; Muzitano, M.F.; Costa, S.S.; Tavares, E.S. Ultraviolet-B radiation effects on phenolic profile and flavonoid content of Kalanchoe pinnata. J. Photochem. Photobiol. B Biol. 2015, 148, 73-81. [CrossRef] [PubMed] 
8. Schreiner, M.; Mewis, I.; Neugart, S.; Zrenner, R.; Glaab, J.; Wiesner, M.; Jansen, M.A. UV-B Elicitation of Secondary Plant Metabolites. In III-Nitride Ultraviolet Emitters; Kneissl, M., Rass, J., Eds.; Springer: Cham, Switzerland, 2016; pp. 387-414.

9. Eichholz, I.; Rohn, S.; Gamm, A.; Beesk, N.; Herppich, W.B.; Kroh, L.W.; Ulrichs, C.; Huyskens-Keil, S. UV-B-mediated flavonoid synthesis in white asparagus (Asparagus officinalis L.). Food Res. Int. 2012, 48, $196-201$. [CrossRef]

10. Schreiner, M.; Krumbein, A.; Mewis, I.; Ulrichs, C.; Huyskens-Keil, S. Short-term and moderate UV-B radiation effects on secondary plant metabolism in different organs of nasturtium (Tropaeolum majus L.). Innov. Food Sci. Emerg. Technol. 2009, 10, 93-96. [CrossRef]

11. Ries, G.; Heller, W.; Puchta, H.; Sandermann, H.; Seidlitz, H.K.; Hohn, B. Elevated UV-B radiation reduces genome stability in plants. Nature 2000, 406, 98-101. [CrossRef] [PubMed]

12. Costa, H.; Gallego, S.M.; Tomaro, M.L. Effect of UV-B radiation on antioxidant defense system in sunflower cotyledons. Plant Sci. 2002, 162, 939-945. [CrossRef]

13. Heo, S.-J.; Ko, S.-C.; Cha, S.-H.; Kang, D.-H.; Park, H.-S.; Choi, Y.-U.; Kim, D.; Jung, W.-K.; Jeon, Y.-J. Effect of phlorotannins isolated from Ecklonia cava on melanogenesis and their protective effect against photo-oxidative stress induced by UV-B radiation. Toxicol. In Vitro 2009, 23, 1123-1130. [CrossRef] [PubMed]

14. Duell-Pfaff, N.; Wellmann, E. Involvement of phytochrome and a blue light photoreceptor in UV-B induced flavonoid synthesis in parsley (Petroselinum hortense Hoffm.) cell suspension cultures. Planta 1982, 156, 213-217. [CrossRef] [PubMed]

15. Sun, M.; Gu, X.; Fu, H.; Zhang, L.; Chen, R.; Cui, L.; Zheng, L.; Zhang, D.; Tian, J. Change of secondary metabolites in leaves of Ginkgo biloba L. in response to UV-B induction. Innov. Food Sci. Emerg. Technol. 2010, 11, 672-676. [CrossRef]

16. Harbaum-Piayda, B.; Walter, B.; Bengtsson, G.B.; Hubbermann, E.M.; Bilger, W.; Schwarz, K. Influence of pre-harvest UV-B irradiation and normal or controlled atmosphere storage on flavonoid and hydroxycinnamic acid contents of pak choi (Brassica campestris L. ssp. chinensis var. communis). Postharvest Biol. Technol. 2010, 56, 202-208. [CrossRef]

17. Flora of China. Ocimum basilicum Linnaeus, Vol.17. Available online: http://efloras.org/florataxon.aspx? flora_id=2\&taxon_id=200019914 (accessed on 5 September 2016).

18. Jayasinghe, C.; Gotoh, N.; Aoki, T.; Wada, S. Phenolics composition and antioxidant activity of sweet basil (Ocimum basilicum L.). J. Agric. Food Chem. 2003, 51, 4442-4449. [CrossRef] [PubMed]

19. Arranz, E.; Jaime, L.; de las Hazas, M.L.; Reglero, G.; Santoyo, S. Supercritical fluid extraction as an alternative process to obtain essential oils with anti-inflammatory properties from marjoram and sweet basil. Ind. Crops Prod. 2015, 67, 121-129. [CrossRef]

20. Kathirvel, P.; Ravi, S. Chemical composition of the essential oil from basil (Ocimum basilicum Linn.) and its in vitro cytotoxicity against HeLa and HEp-2 human cancer cell lines and NIH 3T3 mouse embryonic fibroblasts. Nat. Prod. Res. 2012, 26, 1112-1118. [CrossRef] [PubMed]

21. Viyoch, J.; Pisutthanan, N.; Faikreua, A.; Nupangta, K.; Wangtorpol, K.; Ngokkuen, J. Evaluation of in vitro antimicrobial activity of Thai basil oils and their micro-emulsion formulas against Propionibacterium acnes. Inte. J. Cosmet. Sci. 2006, 28, 125-133. [CrossRef] [PubMed]

22. Salmah, I.; Mahmood, A.; Sidik, K. Synergistic effects of alcoholic extract of sweet basil (Ocimum basilicum L.) leaves and honey on cutaneous wound healing in rats. Int. J. Mol. Med. Adv. Sci 2005, 1, 220-224.

23. Marvat, S.K.; Rehman, F.U.; Khan, M.S.; Ghulam, S.; Anwar, N.; Mustafa, G.; Usman, K.H. Phytochemical constituents and pharmacological activities of sweet basil-Ocimum basilicum L. (Lamiaceae). Asian J. Chem. 2011, 23, 3773-3782.

24. Jenkins, G.I. Signal transduction in responses to UV-B radiation. Annu. Rev. Plant Biol. 2009, 60, 407-431. [CrossRef] [PubMed]

25. Donno, D.; Boggia, R.; Zunin, P.; Cerutti, A.K.; Guido, M.; Mellano, M.G.; Prgomet, Z.; Beccaro, G.L. Phytochemical fingerprint and chemometrics for natural food preparation pattern recognition: An innovative technique in food supplement quality control. J. Food Sci. Technol. 2016, 53, 1071-1083. [CrossRef] [PubMed]

26. Donno, D.; Cavanna, M.; Beccaro, G.L.; Mellano, M.G.; Torello-Marinoni, D.; Cerutti, A.K.; Bounous, G. Currants and strawberries as bioactive compound sources: Determination of antioxidant profiles with hplc-dad/ms. J. Appl. Bot. Food Qual. 2013, 86, 1-10. 
27. Peev, C.I.; Vlase, L.; Antal, D.S.; Dehelean, C.A.; Szabadai, Z. Determination of some polyphenolic compounds in buds of alnus and corylus species by hplc. Chem. Nat. Compd. 2007, 43, 259-262. [CrossRef]

28. Olsson, L.; Veit, M.; Weissenböck, G.; Bornman, J. Differential flavonoid response to enhanced UV-B radiation in Brassica napus. Phytochemistry 1998, 49, 1021-1028. [CrossRef]

29. Hagen, S.F.; Borge, G.I.A.; Bengtsson, G.B.; Bilger, W.; Berge, A.; Haffner, K.; Solhaug, K.A. Phenolic contents and other health and sensory related properties of apple fruit (Malus domestica Borkh. cv. Aroma): Effect of postharvest UV-B irradiation. Postharvest Biol. Technol. 2007, 45, 1-10. [CrossRef]

30. Antognoni, F.; Zheng, S.; Pagnucco, C.; Baraldi, R.; Poli, F.; Biondi, S. Induction of flavonoid production by UV-B radiation in Passiflora quadrangularis callus cultures. Fitoterapia 2007, 78, 345-352. [CrossRef] [PubMed]

31. Rozema, J.; Björn, L.O.; Bornman, J.; Gaberščik, A.; Häder, D.-P.; Trošt, T.; Germ, M.; Klisch, M.; Gröniger, A.; Sinha, R. The role of UV-B radiation in aquatic and terrestrial ecosystems-An experimental and functional analysis of the evolution of UV-absorbing compounds. J. Photochem. Photobiol. B Biol. 2002, 66, 2-12. [CrossRef]

32. Searles, P.S.; Flint, S.D.; Caldwell, M.M. A meta-analysis of plant field studies simulating stratospheric ozone depletion. Oecologia 2001, 127, 1-10. [CrossRef]

33. Berli, F.J.; Moreno, D.; Piccoli, P.; Hespanhol-viana, L.; Silva, M.F.; Bressan-smith, R.; Cavagnaro, J.B.; Bottini, R. Abscisic acid is involved in the response of grape (Vitis vinifera L.) cv. Malbec leaf tissues to ultraviolet-B radiation by enhancing ultraviolet-absorbing compounds, antioxidant enzymes and membrane sterols. Plant Cell Environ. 2010, 33, 1-10. [PubMed]

34. Casati, P.; Walbot, V. Gene expression profiling in response to ultraviolet radiation in maize genotypes with varying flavonoid content. Plant Physiol. 2003, 132, 1739-1754. [CrossRef] [PubMed]

35. Scattino, C.; Castagna, A.; Neugart, S.; Chan, H.M.; Schreiner, M.; Crisosto, C.H.; Tonutti, P.; Ranieri, A. Post-harvest UV-B irradiation induces changes of phenol contents and corresponding biosynthetic gene expression in peaches and nectarines. Food Chem. 2014, 163, 51-60. [CrossRef] [PubMed]

36. Dao, T.; Linthorst, H.; Verpoorte, R. Chalcone synthase and its functions in plant resistance. Phytochem. Rev. 2011, 10, 397-412. [CrossRef] [PubMed]

37. Wade, H.K.; Bibikova, T.N.; Valentine, W.J.; Jenkins, G.I. Interactions within a network of phytochrome, cryptochrome and UV-B phototransduction pathways regulate chalcone synthase gene expression in Arabidopsis leaf tissue. Plant J. 2001, 25, 675-685. [CrossRef] [PubMed]

38. Loyall, L.; Uchida, K.; Braun, S.; Furuya, M.; Frohnmeyer, H. Glutathione and a UV light-induced glutathione S-transferase are involved in signaling to chalcone synthase in cell cultures. Plant Cell 2000, 12, 1939-1950. [CrossRef] [PubMed]

39. Park, J.-S.; Choung, M.-G.; Kim, J.-B.; Hahn, B.-S.; Kim, J.-B.; Bae, S.-C.; Roh, K.-H.; Kim, Y.-H.; Cheon, C.-I.; Sung, M.-K. Genes up-regulated during red coloration in UV-B irradiated lettuce leaves. Plant Cell Rep. 2007, 26, 507-516. [CrossRef] [PubMed]

40. Kontogianni, V.G.; Tomic, G.; Nikolic, I.; Nerantzaki, A.A.; Sayyad, N.; Stosic-Grujicic, S.; Stojanovic, I.; Gerothanassis, I.P.; Tzakos, A.G. Phytochemical profile of Rosmarinus officinalis and Salvia officinalis extracts and correlation to their antioxidant and anti-proliferative activity. Food Chem. 2013, 136, 120-129. [CrossRef] [PubMed]

41. Ghasemzadeh, A.; Jaafar, H.Z.; Rahmat, A.; Ashkani, S. Secondary metabolites constituents and antioxidant, anticancer and antibacterial activities of Etlingera elatior (Jack) RM Sm grown in different locations of Malaysia. BMC Complement. Altern. Med. 2015, 15. [CrossRef] [PubMed]

42. Ghasemzadeh, A.; Omidvar, V.; Jaafar, H.Z. Polyphenolic content and their antioxidant activity in leaf extract of sweet potato (Ipomoea batatas). J. Med. Plants Res. 2012, 6, 2971-2976. [CrossRef]

43. Ghasemzadeh, A.; Talei, D.; Jaafar, H.Z.; Juraimi, A.S.; Mohamed, M.T. M.; Puteh, A.; Halim, M.R.A. Plant-growth regulators alter phytochemical constituents and pharmaceutical quality in Sweet potato (Ipomoea batatas L.). BMC Complement. Altern. Med. 2016, 16. [CrossRef] [PubMed]

44. Castagna, A.; Dall'Asta, C.; Chiavaro, E.; Galaverna, G.; Ranieri, A. Effect of post-harvest UV-B irradiation on polyphenol profile and antioxidant activity in flesh and peel of tomato fruits. Food Bioprocess Technol. 2014, 7, 2241-2250. [CrossRef] 
45. Rybarczyk-Plonska, A.; Hansen, M.K.; Wold, A.-B.; Hagen, S.F.; Borge, G.I.A.; Bengtsson, G.B. Vitamin C in broccoli (Brassica oleracea L. var. italica) flower buds as affected by postharvest light, UV-B irradiation and temperature. Postharvest Biol. Technol. 2014, 98, 82-89. [CrossRef]

46. Harbaum-Piayda, B.; Palani, K.; Schwarz, K. Influence of postharvest UV-B treatment and fermentation on secondary plant compounds in white cabbage leaves. Food Chem. 2016, 197, 47-56. [CrossRef] [PubMed]

47. Javanmardi, J.; Stushnoff, C.; Locke, E.; Vivanco, J. Antioxidant activity and total phenolic content of Iranian Ocimum accessions. Food Chem. 2003, 83, 547-550. [CrossRef]

48. González-Vallinas, M.; González-Castejón, M.; Rodríguez-Casado, A.; de Molina, A.R. Dietary phytochemicals in cancer prevention and therapy: A complementary approach with promising perspectives. Nutr. Rev. 2013, 71, 585-599. [CrossRef] [PubMed]

49. Zarlaha, A.; Kourkoumelis, N.; Stanojkovic, T.; Kovala-Demertzi, D. Cytotoxic activity of essential oil and extracts of Ocimum basilicum against human carcinoma cells. Molecular docking study of isoeugenol as a potent cox and lox inhibitor. J. Nanomater. Biostruct. 2014, 9, 907-917.

50. Arshad Qamar, K.; Dar, A.; Siddiqui, B.S.; Kabir, N.; Aslam, H.; Ahmed, S.; Erum, S.; Habib, S.; Begum, S. Anticancer activity of Ocimum basilicum and the effect of ursolic acid on the cytoskeleton of MCF-7 human breast cancer cells. Lett. Drug Des. Dis. 2010, 7, 726-736. [CrossRef]

51. Heim, K.E.; Tagliaferro, A.R.; Bobilya, D.J. Flavonoid antioxidants: Chemistry, metabolism and structure-activity relationships. J. Nutr. Biochem. 2002, 13, 572-584. [CrossRef]

Sample Availability: Crude extracts of sweet basil leaves are available from the authors.

(C) 2016 by the authors; licensee MDPI, Basel, Switzerland. This article is an open access article distributed under the terms and conditions of the Creative Commons Attribution (CC-BY) license (http://creativecommons.org/licenses/by/4.0/). 